\title{
MANFAAT TEMPE UNTUK KESEHATAN
}

\author{
I Wayan Redi Aryanta \\ Program Studi Kesehatan Ayurweda Fakutas Kesehatan \\ Universits Hindu Indonesia Denpasar
}

\begin{abstract}
Abstrak
Tempe merupakan produk olahan kedelai yang terbentuk atas jasa kapang jenis Rhizopus sp. terutama dari spesies Rhizopus oligosporus, melalui proses fermentasi. Produk tradisional ini sangat bermanfaat bagi kesehatan karena mengandung zat-zat gizi esensial (karbohidrat, protein, lemak, vitamin dan mineral) dan senyawa-senyawa bioaktif yang unggul seperti vitamin B12, antidiare, antikanker, penurun kolesterol jahat, dan antioksidan dalam bentuk isoflavon (daidzein, glisitein, genistein dan 6,7,4 trihidroksi isoflavon). Pangan fungsional ini sangat sesuai untuk dikonsumsi oleh para penderita malnutrisi. Selain itu, tempe bermanfaat untuk mengobati diare, meningkatkan sistem kekebalan tubuh, menjaga kesehatan jantung, menghambat proses penuaan, menurunkan berat badan, memenuhi kebutuhan vitamin B12, mengatasi efek flatulensi, mengurangi risiko Parkinson, meningkatkan kinerja otak, menurunkan kadar kolesterol jahat, dan mencegah berbagai penyakit seperti: penyakit jantung koroner, osteoporosis, penyakit saluran pencernaan, kanker, anemia, diabetes mellitus, dan asma.
\end{abstract}

Kata Kunci : tempe, zat-zat gizi esensial, senyawa-senyawa bioaktif unggul, manfaat bagi kesehatan.

\begin{abstract}
Tempe is a processed soybean product formed by the service of mold type Rhizopus sp. especially from Rhizopus oligosporus species, through the fermentation process. This traditional product is very beneficial for health because it contains essential nutrients (carbohydrates, proteins, fats, vitamins and minerals) and superior bioactive compounds such as vitamin B12, antidiarrheals, anticancer, lowering bad cholesterol, and antioxidants in the form of isoflavones (daidzein, glycitein, genistein and 6,7,4 trihydroxy isoflavones). This functional food is very suitable for consumption by sufferers of malnutrition. In addition, tempeh is useful for treating diarrhea, enhancing the immune system, maintaining heart health, inhibiting the aging process, losing weight, meeting the needs of vitamin B12, overcoming the effects of flatulence, reducing the risk of Parkinson's, increasing brain performance, reducing bad cholesterol levels, and preventing various diseases such as: coronary heart disease, osteoporosis, digestive tract diseases, cancer, anemia, diabetes mellitus, and asthma.
\end{abstract}

Key Words: tempe, essential nutrients, superior bioactive compounds, beneficial for health 


\section{Pendahuluan}

Tempe merupakan makanan tradisional Indonesia yang sudah dikenal sejak berabadabad yang lalu, terutama dalam tatanan budaya makan masyarakat, khususnya di Yogyakarta dan Surakarta.Selanjutnya teknik pembuatan tempe menyebar keseluruh Indonesia sejalan dengan penyebaran masyarakat Jawa yang bermigrasi keseluruh penjuru Nusantara (Sudarmadji et al., 1997; Astawan, 2013).

Sebagai makanan tradisional, tempe memberikan kontribusi yang besar terhadap produsen dan konsumen berpenghasilan rendah dan secara konsisten membantu kehidupan mereka, karena: tempe tersedia setiap saat untuk kebutuhan sehari- hari, teknik pembuatannya sederhana, murah, distribusi pemasaran luas, dan sebagai sumber penghasilan (Sudarmadji et al., 1997).

Saat ini tempe telah merambah ke Manca Negara (Astawan, 2013). Melalui negeri Belanda, tempe telah populer di Eropa sejak tahun 1946. Pada tahun 1984 sudah tercatat 18 perusahaan tempe di Eropa, 53 perusahaan di Amerika, dan 8 perusahaan di Jepang. Di beberapa negara lain, seperti China, India, Taiwan, Srilangka, Kanada, Australia, Amerika Latin, dan Afrika, tempe sudah mulai dikenal meskipun masih di kalangan terbatas.

Harga tempe yang relatif murah, rasanya yang enak, kandungan gizinya yang tinggi, potensi medis yang dimilikinya, dan bisa diolah menjadi berbagai bahan makanan, telah menjadikan tempe semakin populer di masyarakat Indonesia. Para ilmuwan dari berbagai negara terutama Jepang, Jerman, Inggris, dan Amerika Serikat telah banyak melakukan penelitian mengenai tempe, baik ditinjau dari segi gizi, proses pembuatan, maupun aspek medisnya. Beberapa hasil penelitian mereka semakin memperkukuh kedudukan tempe sebagai bahan makanan masa depan yang prospektif (Astawan, 2013).

Tempe sebagai makanan terfermentasi tradisional, dengan bahan baku kedelai dan kultur starter Rhizopus oligosporus, memiliki khasiat yang besar untuk mencegah terjadinya berbagai penyakit degeneratif seperti aterosklerotis, jantung koroner, diabetes mellitus, kanker dan lain-lain (Sudarmadji et al.,1997; Astawan, 2013).

Dalam artikel ini akan dibahas tentang jenis dan proses pembuatan tempe, nilai gizi serta manfaat tempe untuk kesehatan.

\section{Pembahasan}

\section{Jenis dan proses pembuatan tempe}

Di Indonesia ada beberapa jenis tempe (Astawan, 2013), antara lain: tempe gembus (dibuat dari ampas tahu), tempe lamtoro (dari biji lamtoro), tempe benguk (dari biji koro benguk), tempe koro (dari biji koro), tempe bongkrek (dari ampas kelapa), tempe gude (dari kacang gude), tempe bungkil (dari ampas pembuatan minyak kacang), dan tempe kedelai (dibuat dari biji kedelai). Dari berbagai jenis tempe tersebut, yang paling banyak dikonsumsi dan digemari oleh masyarakat adalah tempe kedelai. Umumnya penyebutan tempe berlaku untuk tempe kedelai, sedangkan untuk jenis tempe yang lain disebutkan secara lengkap dengan nama bahan bakunya.

Pada umumnya, proses pembuatan tempe masih dilakukan secara tradisional (turuntemurun) dalam skala industry kecil (Steinkraus,1996; Sudarmadji et al, 1997; Astawan, 2013). Hal inilah yang menyebabkan banyak keragaman yang ditemukan dalam proses pembuatan tempe, baik antardaerah maupun antarprodusen dalam satu daerah yang sama. Secara garis besar, tahap-tahapan penting dalam pembuatan tempe, adalah: pembersihan biji kedelai, perebusan/pengukusan, pengupasan kulit, inokulasi kapang, pembungkusan, dan fermentasi. Proses fermentasi adalah tahap terpenting pada pembuatan tempe. Pada tahap ini, dilakukan pemeraman kedelai selama 3648 jam menggunakan laru (kapangtempe). 
Tempe merupakan produk olahan kedelai yang terbentuk atas jasa kapang jenis Rhizopus Sp, terutama dari spesies $R$. oligosporus, melalui proses fermentasi. Banyak perubahan yang terjadi selama proses fermentasi kedelai menjadi tempe, baik perubahan fisik, biokimia, maupun mikrobiologi, yang semuanya sangat menguntungkan terhadap sumbangan gizi dan kesehatan (Steinkraus, 1996; Sudarmadji et al. 1997; Astawan, 2013).

\section{Kandungan Gizi Tempe}

Komposisi tempe dibandingkan dengan kedelai dapat dilihat padaTabel 1 (Astawan, 2013).Pada Tabel 1 terlihat bahwa kadar protein, lemak, dan karbohidratnya tidak banyak berubah. Akan tetapi karena adanya enzim-enzim pencernaan yang dihasilkan oleh kapang tempe, maka protein, lemak, dan karbohidrat pada tempe menjadi lebih mudah untuk dicerna di dalam tubuh dibandingkan yang terdapat dalam kedelai. Oleh karena itu, tempe sangat baik diberikan kepada semua kelompok umur (dari bayi hingga lansia).

Dibandingkan kedelai, terjadi beberapa hal yang menguntungkan pada tempe. Secara kimiawi hal ini bisa dilihat dari meningkatnya kadar padatan terlaut, nitrogen terlarut, asam amino bebas, asam lemak bebas, nilai cerna, nilai efisiensi protein, serta skor proteinnya. Lebih lanjut tentang mutu gizi tempe dibandingkan kedelai disajikan pada Tabel 2.

Tabel 1. Komposisi zat gizi kedelai dan tempe dalam 100 gram bahan kering

\begin{tabular}{|c|c|c|c|}
\hline ZAT GIZI & KEDELAI & TEMPE & \\
\hline Abu $(g)$ & 6,1 & & 3,6 \\
\hline Protein $(\mathrm{g})$ & 46,2 & 46,5 & \\
\hline Lemak $(\mathrm{g})$ & 19,1 & 19,7 & \\
\hline Karbohidrat (g) & 28,2 & 30,2 & \\
\hline Serat $(g)$ & 3,7 & 7,2 & \\
\hline Kalsium (mg) & 254 & 347 & \\
\hline Fosfor (mg) & 781 & 724 & \\
\hline Besi (mg) & 11,0 & 9,0 & \\
\hline Vitamin B1(mg) & 0,48 & 0,28 & \\
\hline Riboflavin (mg) & 0,15 & 0,65 & \\
\hline Niasin (mg) & 0,67 & 2,52 & \\
\hline Asam pantotenat (mcg) & 430 & 520 & \\
\hline Piridoksin (mcg) & 180 & 100 & \\
\hline Vitamin B12 (mcg) & 0,2 & 3,9 & \\
\hline Biotin (ug) & 35 & 53 & \\
\hline Asam amino esensial (g) & 17,7 & 18,9 & \\
\hline
\end{tabular}

Sumber : Astawan (2013) 
Tabel 2. Komposisi dan Nilai gizi kedelai dan tempe (per gram)

\begin{tabular}{lcc}
\hline FAKTOR MUTU GIZI & KEDELAI REBUS & TEMPE \\
\hline Padatan terlarut (\%) & 14 & 34 \\
Nitrogen terlarut (\%) & 6,5 & 39 \\
Asam amino bebas (\%) & 0,5 & $7,3-12$ \\
Asam lemak bebas (\%) & 0,5 & 21 \\
Nilai cerna (\%) & 75 & 83 \\
Nilai efisiensi protein & 1,6 & 2,1 \\
Skor kimia & 75 & 78 \\
\hline Suber & &
\end{tabular}

Sumber : Astawan (2013)

Menurut Hermana et al.1996 dalam Astari (2019), perbandingan gizi antara tempe dan daging dalam 100 gram penyajian sebagai berikut (Tabel 3).

Tabel 3 menunjukkan bahwa semua zat gizi yang terkandung dalam tempe (kecuali lemak) lebih tinggi dibandingkan dengan daging. Selain itu, tempe juga mengandung suatu zat antioksidan dalam bentuk isoflavon yang sangat dibutuhkan oleh tubuh untuk menghentikan reaksi pembentukan radikal bebas sehingga dapat menghambat proses penuaan, mencegah berbagai penyakit, seperti : diare, penyakit jantung koroner, diabetes mellitus, kanker, osteoporosis dan lain-lain.

Tabel 3. Perbandingan gizi antara tempe dan daging dalam 100 gram penyajian

\begin{tabular}{lcc}
\hline ZAT GIZI & TEMPE & DAGING \\
\hline Protein (g) & 20,7 & 18,8 \\
Lemak (g) & 8,8 & 14,0 \\
Karbohidrat (g) & 13,5 & - \\
Serat (g) & 3,2 & - \\
Kalsium (mg) & 155,1 & 10,0 \\
Fosfor (mg) & 323,6 & 170 \\
Besi (mg) & 4,0 & 2,8 \\
Thiamin (mg) & 0,12 & 0,08 \\
Riboflavin (mg) & 0,29 & - \\
Niacin (mg) & 1,13 & - \\
Asam pantotenat (ug) & 232,4 & - \\
Piridoksin (ug) & 44,7 & - \\
Biotin (ug) & 23,7 & - \\
Vitamin B12 (ug) & 1,7 & 1,4 \\
\hline
\end{tabular}

Sumber : Astari (2019)

Selama proses fermentasi tempe terjadi peningkatan derajat ketidakjenuhan terhadap lemak, sehingga asam lemak tidak jenuh majemuk (polyunsaturated fatty acids $=$ PUFA) meningkat jumlahnya, seperti asam oleat dan linolenat (asam linolenat tidak terdapat pada kedelai). Asam lemak tidak jenuh mempunyai efek penurunan terhadap kandungan kolesterol pada serum, sehingga dapat menetralkan efek negatif sterol di dalam tubuh (Astawan, 2013).
Dua kelompok vitamin yang terdapat pada tempe, yaitu: vitamin larut air (vitamin B kompleks) dan vitamin larut lemak (vitamin A, D, E, K). Tempe merupakan sumber vitamin $B$ yang sangat potensial. Vitamin B12 kenaikannya paling mencolok pada pembuatan tempe (33 kali selama fermentasi), sehingga tempe menjadi satu-satunya sumber vitamin B12 dari bahan pangan nabati. Vitamin B12 tidak diproduksi oleh kapang tempe, tetapi oleh bakteri kontaminan, yaitu Klebsiella pneumoniae dan Citrobakter 
freundii (Steinkraus, 1996; Sudarmadji et al.,1997; Astawan, 2013).

Vitamin B12 sangat diperlukan dalam pembentukan sel-sel darah merah, dimana kekurangan ini mengakibatkan terjadinya anemia pernisiosa, dengan gejala: pucat, sakit perut dan berat badan menurun. Dengan adanya vitamin B12 pada tempe, maka para vegetarian tak perlu khawatir akan kekurangan vitamin B12 sepanjang mereka melibatkan tempe dalam menu hariannya (Astawan, 2013).

Tempe dapat menghasilkan enzim fitase yang akan menguraikan asam fitat (yang mengikat beberapa mineral) menjadi fosfor dan inositol. Dengan terurainya asam fitat, maka mineral-mineral tertentu (besi, kalsium, magnesium, seng) menjadi lebih tersedia untuk dimanfaatkan tubuh. Oleh karena itu, maka konsumsi tempe secara teratur akan menghindarkan seseorang dari anemia akibat kekurangan zat besi (Astawan, 2013).

Di dalam kedelai terdapat 3 jenis isoflavon sebagai antioksidan, yaitu daidzein, glisitein, dan genistein. Pada tempe, disamping ketiga jenis isoflavon tersebut, juga terdapat antioksidan faktor II $(6,7,4$ trihidroksi isoflavon) yang mempunyai sifat antioksidan paling kuat dibandingkan isoflavon dalam kedelai. Antioksidan ini disintesis pada saat terjadinya proses fermentasi kedelai menjadi tempe oleh bakteri Micrococcus luteus dan Coreyne bacterium. Apabila makanan yang dikonsumsi mengandung senyawa antioksidan yang cukup, maka proses penuaan dapat dihambat, sedangkan kanker prostat dan kanker payudara dapat dicegah oleh genistein (Steinkraus, 1996; Sudarmadji et al., 1997; Astawan, 2013).

Selain mengandung zat-zat gizi yang sangat dibutuhkan oleh tubuh, kedelai mentah juga mengandung zat-zat antigizi yang merugikan kesehatan, seperti antitripsin, antikimotripsin, tanin, saponin, asam fitat, dan hemaglutinin. Dengan adanya proses fermentasi kedelai menjadi tempe, maka komponen-komponen antigizi tersebut menjadi inaktif sehingga tidak lagi berbahaya bagi tubuh (Astawan, 2013).

\section{Manfaat Medis dari Tempe}

1. Meningkatkan Sistem Kekebalan Tubuh. Tempe mengandung berbagai jenis bakteri baik (probiotik) dan antioksidan isoflavon. Oleh karena itu, mengonsumsi tempe akan membantu meningkatkan imunitas atau sistem kekebalan tubuh (Astawan, 2013; Azizah, 2020).

2. Mencegah Osteoporosis. Kandungan kalsium dan vitamin $\mathrm{K}$ yang cukup tinggi pada tempe bermanfaat untuk pembentukan tulang, sehingga osteoporosis dapat dicegah ( Steinkraus, 1996; Sudarmadji et al., 1997; Azizah, 2020).

3. Mengobati Diare. Kemampuan tempe untuk mengobati diare disebabkan oleh zat antidiare dan protein tempe yang mudah dicerna dan diserap (Astawan, 2013). Menurut Sudarmadji et al. (1997), tempe mengandung zat-zat antibakteri yang mampu mengatasi berbagai penyakit infeksi seperti diare.

4. Menjaga Kesehatan Jantung. Menurut Azizah (2020), antioksidan dan antiinflamasi yang terkandung pada tempe mampu melindungi pembuluh darah dari kerusakan inflamasi dan oksidatif sehingga membuat jantung sehat.

5. Mencegah Penyakit Jantung Koroner. Penyakit jantung koroner merupakan salah satu bentuk kelainan pembuluh darah koroner akibat penumpukan lemak di dalam dinding pembuluh darah yaitu suatu keadaan yang disebut aterosklerosis. Tempe dapat digunakan untuk mencegah penyakit ini karena tempe mengandung zat-zat yang mempunyai sifat hipokolesterolemik (menurunkan lemak darah), yaitu: protein, asam lemak tidak jenuh majemuk, serat pangan, niacin, vitamin $\mathrm{E}$, karotenoid, isoflavon dan kalsium (Sudarmadji et al.,1997; Astawan, 2013).

6. Mencegah Berbagai Penyakit Saluran Pencernaan. Menurut Astawan (2013), adanya serat pangan 
yang cukup tinggi pada tempe mampu mencegah penyakit saluran pencernaan, seperti diverticulosis (borok pada usus besar), kanker, dan hernia. Selain itu, enzim lipase, protease, dan amilase yang diproduksi oleh Rhizopus sp (kapang tempe) yang masing-masing berguna untuk pencernaan lemak, protein, dan karbohidrat sangat membantu proses pencernaan makanan di dalam tubuh (Steinkraus, 1996; Sudarmadji et al.,1997; Astawan, 2013).

7. Mencegah Kanker. Kandungan antioksidan isoflavon, seperti daidzein, glisitein, genistein dan 6,7,4 trihidroksi isoflavon pada tempe dapat mencegah kanker (Sudarmadji et al., 1997; Astawan, 2013). Hasil penelitian di Universitas North Carolina USA menemukan bahwa genistein dapat mencegah kanker prostat dan kanker payudara (Astawan, 2013).

8. Mencegah Anemia. Rendahnya kandungan haemoglobin dalam darah merupakan indikasi penyakit anemia. Penyakit ini dapat dicegah dengan mengonsumsi tempe karena tempe mengandung protein, zat besi, vitamin B12, asam folat, tembaga dan seng yang sangat dibutuhkan untuk sintesis haemoglobin (Sudarmadji et al. 1997; Astawan, 2013).

9. Mencegah Diabetes Mellitus. Penyakit ini dapat dicegah karena tempe mengandung protein, serat pangan, dan isoflavon yang mampu menjaga keseimbangan gula darah dan memperbaiki resistensi insulin (Astawan,2013; Azizah, 2020).

10. Mencegah Asma. Penyakit ini dapat dicegah karena serat pangan dan asam lemak tidak jenuh esensial (asam oleat, linoleat, linolenat) yang terkandung pada tempe mampu mengurangi tingkat peradangan terkait respon pernapasan dan memperkuat sel-sel kekebalan di paru-paru (Azizah, 2020).

11. Mengurangi Resiko Parkinson. Penyakit ini ditandai oleh gangguan neurologis atau sistem saraf pusat yang tidak normal, sehingga tingkat dopamine menurun. Niacin pada tempe mampu untuk memperbaiki sel-sel saraf yang terganggu sehingga dapat mengurangi resiko penyakit parkinson (Azizah, 2020).

12. Menghambat Proses Penuaan. Aktivitas antioksidan (isoflavon) pada tempe berhubungan dengan aktivitas potensial untuk menghambat proses penuaan (Sudarmadji et al.. 1997).

13. Menurunkan Kadar Kolesterol Jahat (low density lipoprotein/LDL). Isoflavon dan niacin yang terkandung pada tempe telah terbukti sangat efektif menurukan kolesterol jahat secara alami bagi mereka yang berada pada peningkatan risiko serangan jantung dan stroke karena memiliki kadar kolesterol LDL dan trigliserida yang tinggi serta kadar kolesterol baik (HDL) yang rendah (Astawan, 2013; Azizah, 2020).

14. Menurunkan Berat Badan. Bagi mereka yang mempunyai program diet untuk menurunkan berat badan, tempe merupakan makanan yang tepat karena mengandung probiotik untuk melancarkan pencernaan dan berbagai nutrisi yang dibutuhkan oleh tubuh (Azizah, 2020).

15. Meningkatkan Kinerja Otak. Menurut Azizah (2020), mineral mangan dan tembaga yang terkandung pada tempe berpengaruh baik terhadap kinerja otak.

16. Mengatasi Efek Flatulensi (Perut Kembung). Perut kembung yang dialami oleh seseorang yang mengonsumsi kedelai dapat diatasi dengan mengonsumsi tempe, karena senyawa karbohidrat raffinosa dan stakhiosa yang terkandung pada kedelai yang tidak tercerna dalam sistem percernaan manusia mengalami hidrolisis oleh enzim amilase selama fermentasi,sehingga efek flatulensinya dapat dihilangkan (Astawan, 2013).

17. Memenuhi Kebutuhan Vitamin B12. Vitamin B12 yang terkandung pada tempe sangat dibutuhkan oleh 
tubuh manusia terutama para vegan dan vegetarian untuk pembentukan sel-sel darah merah (Astawan, 2013).

\section{Simpulan Dan Saran}

\section{Simpulan}

Dari uraian di atas dapat disimpulkan sebagai berikut:

1. Tempe merupakan produk olahan kedelai yang terbentuk atas jasa kapang tempe dari jenis Rhizopus Sp. terutama dari spesies $R$. oligosporus melalui proses fermentasi.

2. Ditinjau dari segi gizi dan khasiat medis, tempe merupakan makanan yang sehat bagi semua kelompok umur (dari bayi sampai lansia).

\section{Saran}

Mengacu kepada pola makan empat sehat lima sempurna untuk meningkatkan kesehatan, disarankan menggunakan tempe sebagai lauk pauk pada setiap menu yang dihidangkan setiap hari.

\section{DAFTAR PUSTAKA}

Astari, G.R. 2019. 5 Manfaat Makan Tempe Bagi Kesehatan. https://hellosehat.com-fakta-unik (diakses tanggal 11 April 2019).

Astawan, M. 2013. Jangan Takut Makan Enak: Sehat Dengan Makanan Tradisional. Jilid 2. PT Kompas Media Nusantara. Jakarta.

Azizah, K. 2020. 12 Manfaat Tempe Bagi Kesehatan, Makanan Murah Dengan Khasiat Mahal. https://w.w.w.merdeka.com/trending (diakses tanggal 12 April 2020).

Steinkraus, K,H. (ed). 1996. Handbook of Indigenous Fermented Foods. Second Edition, Revised and Expanded. Marcel Dekker, Inc. New York.

Sudarmadji, S., Suparmo, and S. Raharjo (eds). 1997. Reinventing The Hidden Miracle of Tempe. Indonesian Tempe Foundation. Jakarta. 